\title{
The Effect of Public Sector Reform on Good Governance in Somalia
}

\author{
Mohamed Omar Bincof \\ Ph.D. Candidate, Department of Political Science and Public Administration at Ankara Yıldırım Beyazıt \\ University Turkey, Ankara
}

\begin{abstract}
This paper aims to examine the effects of recent reforms on Somalia's public sector and whether these changes will lead to the adoption of good governance practices. Somalia's public sector has experienced immense challenges since the civil war broke out in 1991. Although some level of peace and reorganization has occurred in the country, lack of full support for the government, nepotism, corruption, and political instability continues to undermine efforts of achieving good governance. This paper revisits a less focused on the question of public sector reforms, which is often overlooked in policy and research in place of discussion on conflict and state fragility. Limited efforts have been made to explore the progress and impact of reforms in the Horn of Africa country. The study finds that amid the efforts by the government and development partners to bring reforms to Somalia, there is still room for more changes. The paper concludes with a set of recommendations that can help the country push its public-sector reform agenda forward.
\end{abstract}

Keywords: public sector reform, good governance, Somalia

DOI: $10.7176 /$ PPAR/10-9-09

Publication date:September $30^{\text {th }} 2020$

\section{Introduction}

Over the past three decades, trends and challenges in the public-sector reforms (PSR) have caught the attention of researchers and scholars seeking to understand the impact of such changes on good governance practices. The main goal of implementing good governance practices has been to ensure efficiency and effectiveness within the government when it comes to social service delivery. The public sector is often considered the core variable through which citizens can evaluate their government's performance (Agwanda, 2019). It is therefore essential to understand the main objectives of public sector reforms. Similarly, it is important to note that more systematic efforts to bring about good effectiveness and efficiency in government can be traced back to the 1980s when New Public Management practices were introduced. International financial institutions include the world bank, IMF, and other vital institutions working finical economic systems, have been alarming the significance of enhanced public-sector accomplishment in countries around the world. In this regard, I became interested in examining the public sector after reading the growing trends of Somalia's public management progress. A broader perspective has been studied by Grindle (2013) argues that the complexity of the process of reforming the public sector is hindering those who operate in the area since they are certainly no 'science' of what is most significant in reform. It will keep our minds that reform ideas are always occasional or infrequent (Grindle, 2013). The efficiency and effectiveness of Somalia's public sector are essential to attain sustainable development and good governance. In that case, the article adopts two primary areas of public sector reform that support The World Bank, such as civil servant reform, and tax and administrative policy. All are recognized to lead good governance. The poverty reduction strategy programs enable governments to generate their terms in the arranging of three national development plans (NDP). The international monetary fund and the World Bank may determine whether the country's poverty reduction strategy paper merits the pardoning of debts or extra of new loans.

The involvement of central governments attempted to diminish an essential characteristic of structural adjustment programs: the connection in which international financial institutions (IFIs) order relevant policy for beneficiary states (Jibril, 2017). In light of recent development, public sector reform has become more assertive, widespread, and increasingly associated with good governance. Thus, many governments and international financial organizations have frequently demanded benefiting countries to accelerate public sector reforms in order to achieve government effectiveness. Moreover, many difficulties may arise when it comes to the implementation of sector reforms. The main challenge faces governments and international organizations that support PSR's is a lack of leadership commitment and the limited capacity of public institutions. It has also revealed that many developing countries struggle to originate public sector reforms at the first stage (Bunse and Fritz, 2012). In particular, Dipholo and Gumede (2014) found that most African states are individualized and characterized by systematic corruption, nepotism, bureaucratic mismanagement, and little compliance to the rule of law be it in the procurement process, recruitment process, or resource allocation and distribution. Their analyses Dipholo and Gumede (2014) highlighted that the principles of good governance were entirely lacking on the African continent. These sentiments are echoed by Balogun (2005) who argues that "As part of the efforts at rewarding the growing demand for democracy dividends, African Governments have in recent years shifted attention to the reform of the 
public service" (pp:2).

In Somalia, the transformation experienced by public sector reforms over the past three years remains a work in progress. This process has benefited from initiatives by the government and other development partners such as the World Bank under a multi-partner fund project which intends to facilitate the government priorities to improve two key areas in the public sector namely, reforming revenue and expenditure management, strengthening advanced civil service. Westhuizen's views (2005) argue that traditional public-sector reform activities have focused on efforts aimed at rescuing countries from the financial or economic crisis. The former permanent secretary office of the prime minister Mr. Keynan (2017) points out that "there are many good reasons why implementation of public sector reform in Somalia is needed" (World Bank, 2017). Noted that PSR is the heart of government initiative to enhancing public institutions through policy reforms, merit-based recruitment, and equity. He mentioned the multi-partner fund (MPF) could be a significant engine for these reforms. According to Transparency International, Somalia has been one of the most corrupt counties in the world over the last decade, and the country got the lowest score (9) in the year 2019 (Transparency International, 2019). According to a report by Integrity, Somalia's public sector continues to suffer from lack of an effective tax administration system, bribery is common in entire public sectors, and procurement contracts often involve corruption (Integrity, 2016). This study's primary purpose is to assess how different dimensions of Public sector reform can help to bring about the much-needed principles of good governance in Somalia's public sector. The paper has focuses on investigating two different dimensions /types of public sector reform: strengthening civil servants, and revenue and administrative policy. Also, examines the changing nature of public sector reform in Somalia, assesses the significance of two dimensions, and how they could bring a certain level of good governance.

Understanding the link between public sector reform and good governance will help me to provide new solutions to research objectives. The findings will make an essential contribution to the field of PSR and GG. It also helps the federal institutions, donors, or the international community who gives direct financial support to Somalia's government and the people of Somalia, it probably informed of the importance of different types of the public sector to good governance. Progressively international recognition of the demand for good governance appeared merely from the 1990s forward. While various essence of good governance occurs, the word commonly connected with economic, political, and social objectives that are considered required for attaining evolvement. Therefore, good governance is the process whereby government institutions perform public affairs and control national resources in a way that advances the rule of law and fulfill the human rights principles.

\section{Theoretical Framework}

This section addresses the forms of waves that characterized reforms in the public sector of African countries. It adopts the theory of Public Choice to explain the underlining theoretical elements of PSRs. The motive for the section is to obtain a broad understanding of the possible relevant public-sector reform in driving good governance, economic development, and strengthening government effectiveness. The public choice theory helps the research to draw a critical theoretical basis to interrogate the case study. The public choice is based on the assumption that public bureaucracies are careless to changes the environment together with unresponsive to the public beneficiaries. Also, this theory is the response increasing the concept of new public management which is linked with rising the prominent and intellectual disillusionment for the role of the government, growth, and rising taxation. Consequently, the power to control the extension of the government and move to privatization (Hood, 1991). In that context, the theory underpins the key areas that Somalia's government seeks to advance in terms of PSR such as tax administration and strengthen civil servants. Kazeem et al. (2016) observers that public services performance, financial management, civil service management has not improved as well as linked with corruption and lack of accountability. Moreover, previous reform efforts were made to enhance African nations with conditions of the rising global economy, demanding governments in Africa countries. Nevertheless, the reality remains unchanged; the outcomes attained stand some extent poor and socio-economic conditions of several African countries that have initiated reforms have even, in most cases, dysfunctional (Kazeem et al. (2016). This study, therefore, investigates how two critical dimensions in PSR might have an influence on good governance in Somalia.

\section{Forms of Waves of public sector reforms}

In recent years, there has been an increasing interest in analyzing the waves of public sector reforms (Agwanda, 2019). Three different waves of PSRs have been reported in Africa: the first wave started in the 1980s, the second wave began in the 1990s, and the third wave was in the 2000s. During the first wave of reforms in the continent that begun most of the reforms were undertaken under the best of structural reforms. These reforms aimed to focus on the macroeconomic and fiscal elements of the African countries, which were experiencing economic crises and general struggle with driving the economies to development. The initial wave of PSRs was supported by the IMF and the World Bank. They intended to eliminate excessive government expenditures emerging from a bloated public sector human resource and a sagging wage bill. This was further worsened by corruption and weak productivity. Other key motives behind these reforms involved in an established clear separation of roles between 
levels of government (local and National), The reform process also involved the active participation of other sectors. Under the reforms, the state was supposed to play a critical role in ensuring that there is an enabling condition that could promote the growth of the private sector, safeguarding attaining effective decentralization of public services; and, privatization, substituting public entities (Kiragu and Mutahaba 2002). During this period the case of Somalia was not reported in the literature for structural reform.

The second wave was characterized by attempts to help developing countries advance in a capacity-building especially of their public sector works. The aim was to respond to the deficiencies and obstacles experienced during the implementation of the structural adjustment program during the first wave. However, the 1990s was deemed as the "lost decade" for Africa and many other parts of the world as the impact of various global economic crises that culminated with the 1998 economic crush. In Africa, there was severe economic turmoil by the rapid decline in the prices of primary products and natural resources that many African economies depended on. Furthermore, there were growing national debts, high levels of unemployment, a faster-increasing population, unproductive or shortage of water, and conflicts related to ethnicity. In the same period, Somalia has been devastated by clan-based conflicts, armed groups, instability, and famine. Ayee (2005) claims that these obstacles were advanced by a complex mix of over politicization of the public sector through discriminatory recruitment, extended workforce, deep-rooted rampant corruption, and lack of accountability.

These widely affected public sector provisions of goods and services. Thus, it required different reforms to be introduced in the public sector to improve government efficiency and effectiveness over actions such as the privatization of public entities. The second wave also involved the training of civil servants to strengthen their skills, enhance the work conditions to motivate public employees, improve the structures of management, and rebuild measures to encourage staff, through higher paid or terms of service (Stockholm, 2005). In the course of the wave of capacity building, the World Bank has played a leading role in extending assistance to African states including Somalia in terms of financial and technical support. The World Bank granted financial loans for public sector reforms in the above four African countries. Thus, Though the transforms aimed to enhance capacity in the public sector, rampant corruption and other immoral behavior were rooted in the general causes resulting in a more significant decline of public services (Moussa, 1992). Recently in March 2020, the world bank provided Somalia $\$ 140$ million for expanding financing development and poverty reduction (World Bank, 2020).

The third wave featured service enhancement in the public sector. These efforts begun in the year 2000s concentrated on public service performance through different indicators, underscoring the attainment of annual objectives of the public sector. Executives officer have to turn into more significant accountable to the government and public by yearly audit investigation and utilize public resources. It should be noted, this stage despite continuing consistency, the development still quite slow as a result of the poor execution of capacities that remain confront African states and the low wages of civil servants. Despite that, this stage introduces a unique window of opportunity to contribute, taking into account entire civil servants and drive increased transparency in the public sector (Agwanda, 2019). As stated by Karyeija (2012), this wave addresses on the public management techniques, budgetary, and outcome-oriented management to enhance social service delivery to the citizens. The third wave is keen on focusing on actions that can lead to more accountability, and transparency, recruitment of innovative, skilled and competent management in the public sector. It advocates for increased civic engagement and participation in public decision-making processes; challenging for timeline outcome on delegated authorities from appropriate levels of leadership, and the consolidation and adoption of a cross-sectoral method to social service delivery. Equally important, the third wave is also associated with the poverty reduction efforts by calling for more inclusivity of several actors in government strategic short- and long-term development agendas or planning. As observed by Ayee (2008), the third wave emphasizes regulated, effective and efficient utilization of government resources that optimize the output of the government sector scheme. Though these reforms have led to expectations of development on the continent in terms of human and natural resources, the impact to date still lacks the strong conviction and that the potential advantages of the public-sector reforms are still to be extensively experienced in the continent particularly when it comes to addressing development and service delivery (Ayee, 2008).

Indeed, there is no shortage of example of countries in Africa which have implemented reforms in the public sector. Antwi et al., (2008) mentioned while presenting the case of reforms in Ghana, they point out that within the framework for economic resilience and structural transformation launched in 1983 the government implemented policies aimed at downsizing in the civil service workforce that decreased the public employees from 301,000 in 1986 to 260,000 by 1990 bring a total government labor cost to diminish of $4.5 \%$ to the GDP. Moreover, Mwenda et al., 2005 illustrated that Uganda had performed significant reforms that decreased the government workforces by around above 50 percent from 320,000 to 147,000. Zambia and Kenya remarkably had different approaches and experiences from the other two countries Uganda and Ghana. What remains constant, however, is that irrespective of the different approaches by various African countries, these reforms are yet to yield significant fruits. In addition, budget cuts in Kenya were implemented through a voluntary pre-retirement program that came with a comprehensive retirement package. These efforts were diluted with the mass recruitment of teachers exercise by the government, which means that there was a slight impact in trying to reduce the government wage 
bill (Rono, 2002).

In Zambia, execution of the structural adjustment plans started in 1997 when the government embarked on a retrenchment program downsize government employees by around 37,000 workers in three years (Loxley, 1990). As reported by Mutahaba et al. (2002), the structural adjustment wave had few effects in enhancing social service delivery in the public sector. Despite the optimism, the reforms in the said countries faced an uphill task as various deep-rooted socio- economic and political factors undermined the effectiveness of these reforms to deliver effective and efficient social service provision. Of importance, to fulfill the needs of broader development qualified professionals and specialized workforce should dominate key sectors such as health, agriculture, manufacturing, and education. In a study of Somalia's agricultural sector, it was revealed that some structural adjustment program policies were counterproductive discouraging development, instead of advancing it (Mutahaba et al. (2002).

For instance, the government and international partners like IMF and the World Bank supported the capacity injection mechanism which aims to support the government minister to recruit qualified civil savants and advisors to carry out the vital strategic and management capacity required. On the other hand, the program's sustainability has not been appropriately examined regarding execution capacity and long-term fiscal continuity. Accomplishments under the capacity injection mechanism (CIM) was unsatisfactory. There has been overstated on enhanced salary the newly recruited officers instead of restructuring; numerous transformations have been slightly insignificant, and upholding merit-based appointment structures has demonstrated complex (Tran, 2019). To provide an analytical research response, the article used qualitative methods that could be more useful for identifying and characterizing the research sources. The paper adopted a qualitative approach to discuss and examine the issue surrounding the public-sector reform and good governance in Somalia. It also focused on the current and previous trends and the development of various areas such as tax and administration policy, civil service system. The article collected data and analyzed from different sources such as official government reports, documents, and other international reports studies were investigated based on explanatory and analytical method.

\section{Somalia's Public-Sector Reform and good governance}

Somalia's public reform operations have been in progress since 2017. The country has increasingly continued to benefit from increased grants from the World Bank targeting PSRs. For the first time in 30 years, the World Bank has approved $\$ 80$ million in grants to Somalia to support public finance reform in 2018 (Reuters, 2018). Since 1981 The IMF and The World Bank started conducting SAPs in the country. In Somalia, the Structural adjustment program presided to reduced government spending on social delivery series in particular education, health, security, and law enforcement. To ensure the adoption of structural adjustment programs on the beneficiary state, multinational lending organizations usually matched the economic plan with food assistance or adjustment. Unlike food assistance schemes in Somalia, nevertheless, disrupt the country's agriculture sector and following contributed to the harsh hunger in Somalia (Jibril, 2017). Despite the great collapse of structural adjustment programs in advancing evolvement and reducing poverty, the plans remain to prevail through a different title. During 1999, the structural adjustment programs were interchanged with PRSPs alternatively the IMF and World Bank developing conditions applying for loans. Currently, Somalia needs to tackle several obstacles for achieving sustainable development, in other words given the country has faced over 30 years of conflict and vulnerability however, significant progress has been made so far in terms of PSR. The federal government has inherited a weak economy and straggling to confront high levels of inequality and poverty a rising young population which demands job creation, a high level of unemployment, and a vast number of infrastructure gaps (World Bank, 2015). That said, one cannot overlook the progress made over the past three years, especially with the reforms undertaken in the budget planning and implementation process with improving public finance management and open reporting (IMF, 2020). Given that poverty is a multi-dimensional aspect that affects different forms of socio-economic, health, education, and life quality indicators, governments have been encouraged to restructure and reform themselves to provide solutions to these challenges (MoP, 2020).

According to the World Poverty report (2020) indicates the number of people living in extreme poverty in Somalia is estimated at 81 percent of the total population of 16 miilion. Purchasing power parities about $\$ 1.90$ per day. Nevertheless, the main challenge facing donor and development organizations today is how to get chance the vulnerable people of Somalia in the participation of designing a course for a comprehensive social, economic, and political evolvement plan (The World Bank, 2020). Eliminating dire poverty will need reaffirmed prioritize states and Sub-Saharan Africa misfortunate from weak public institutions and conflict. (World Bank, 2018). Some writers (e.g., Schacter, 2000; Ayee, 2005) demonstrate that the outcome of PSR has been mostly unsuccessful if not harmful (Schacter, 2000) As Weber expressed, "Every reform, however necessary, will be weak by minds carried to an excess, that itself will need reforming (Weber, 2017). As previous research indicates that various moderndeveloped nations have established merit-based public employee systems that took many years to develop and execute. For instance, even so, some western countries were initiated in the nineteenth century to integrate their public service systems. The importance of systematic and consistent is to highlight that the required reforms lead to permanent alters in public sector actors' attitudes in the benefits of more significant results for the public. 
The goal of the World bank's capacity injection program is to improve the capacity for (10) federal government institutions. The program presented a new, proper selection process and infused crucial personnel to heart public institutions. The program might respond as a pilot appraisal for a higher government-led public service reform in the nearest future. UNDP's project has also assisted civil service reform, consisting of a revisit of the civil service law no. 11. The federal government, which came to power in 2017, initiated particular measures to reform the public service. The government suspended the recruitment of new civil servants not just because of the absence of resources, however, as well as the result of the requirement to reforming civil service and the poor recruitment processes. Moreover, to enhance working hours of public servants and regular salary payment of public employees, the government redesign the structure of public service institutions by wipe out $g$ the 'Permanent Secretary' post of entire but only ministries. The federal government expected to start the recruitment of full Director-General positions (Wasuge, 2018). To build a professional and competitive civil service, the government should ensure establish a centralized examination for all new public employees and developing with the employ of technology for application and selection processes. Furthermore, the law 11, should be suspended and introduce the legislation that should meet the relevant standard of public recruitment, development, and appraisal.

Rationally, the current civil service should revise and assess the staff's capacity while necessary to downsize the unproductive staff while also hiring new competent public service. An extensive civil service reform program would require political determination and promises from the related policy-making bodies or authorities in the federal government of Somalia, comprising office of the president and PM and Ministry of labor. The civil service should overcome the political landscape. The politicization of the public service, as until date been the case, gives rise to administrative failures and causes favoritism-based civil service recruitment (Wasuge, 2018). Important to realize that civil service and administrative also has the most general dimension of Public sector reform. The critical matter of attractiveness of salary costs usually guided to stress on salary reduction and politically impractical changes. To achieve a competent civil service management system, the government should enhance its employee's performance and figure out the necessary talent for public employees that will positively impact good governance. The efficiency and effectiveness of a nation's public sector are essential to the achievement of development activities, containing those the World Bank assists in approaching such inquiries. The Independent Evaluation Group has investigated loaning and other types of Bank loans in support of public sector reform in the period between 1999 and 2006 in areas mentioned previous pages. According to the World Bank good governance indicators: There six measurement of GG which the world Bank regular evaluates more than 200 states and regions across the globe includes; Manage Corruption, Government Effectiveness, And lack of Violence Political Stability, Sound and Accountability, Regulatory Quality and Rule of Law. In the modern global governance, PSRs have become a central issue for both developed and developing countries, with hopes that reform will advance good governance. According to the World Bank independent evaluation group 2008, pointed out about 467 loaning projects was intended PSR from 1990 to 2006 the public-sector reform became major components of world Bank's grants.

Those lending projects represent nearly \$20 billion in arrangements planned for PSR. From 1997 to 2007 the public sector and governance plan were authorized, and anti-corruption was included directly to the plan (World Bank Group, 2008). Public service institutions are supposed to be clean of corruption and practice good governance principles. According to Helao, "good governance practices" enhance public service execution and eventually improves service delivery (Helao, 2015, p. viii).

On the other hand, the benefits of good governance assumed that every country implementing sound governance principles would succeed in economic growth and consistent development. While obtaining more support and investment, enlarge human development, accomplish a high democratization process, effective government and, a decrease of poverty, and contribute to reconstruction post-conflict countries like Somalia. The country is still struggling to reach the IMF decision point to get debt relief which is estimated 5Billion USD. Subsequently, Somalia will address structural reform. In that context, the article focuses on two primary dimensions: revenue mobilization, civil servant reform, but the world bank supports countries around the world in terms of other areas including public financial management, and anti-corruption and transparency measures. Most of the states that lent to support the Public sector experienced and enhanced performance to some extent (The World Bank, 2008). The author is interested in investigating these two primary areas of PSR, which was introduced by the world bank and implemented many countries including Somalia which traces to benefit those projects funded by the world bank and intended to support PSR. Over the past three years, PSR was crucially important because the country has 5.1 Billion external debt, therefore, to get access to debt relief, IMF and the world bank demanded to implement on PSRs and supported millions of dollars.

\subsection{Revenue and tax administration reform}

It believed that revenue Management and tax administration commonly achieved and supported by stable government possession, ministries, especially finance, and good identifying and strategy usually directed by the IMF. Since the country adopted federalism, the tax administration system has not agreed with the federal 
government and a national member state of Somalia. For instance, revenue sharing, federal tax, custom legislation, and other crucial harmonization of taxation remain under discussion (The world bank, 2017).

Table 1: Summary of revenue and expenditure for the year 2017-2018-2019

$\begin{array}{ccccc}\text { In US\$ Million } & 2017 & 2018 & 2019 & \begin{array}{c}\text { Change in } \\ \text { amount } \\ \text { National Budget }\end{array} \\ 248.3 & 297.1 & 344.2 & 47.1\end{array}$

Source Ministry of finance (2019:.8)

What is interesting about the data in this table is that there was a significant increase in the national budget over the past years after massive reform made by the government under the instruction of IMF and the World Bank. Nevertheless, the country is struggling to fight corruption and increase its domestic revenue. Recently, Dalsan Radio published a report indicates Six officials of Mogadishu's port tax authority, including the director, had been arrested over corruption allegation. The report shows that $\$ 7000$ had fraudulently been taken (fraudulently) from a local company for a bribe in pledged tax reduction (Dalsan, 2019). Even though the federal government of Somalia faces significant problems in collecting domestic revenue. Furthermore, the key problem tax collection is associated with the lack of a consistent tariff arrangement for evaluating custom movements.

That makes it difficult to determine the actual number of tariffs as several goods arrive in the country through unauthorized border-crossing points thus avoiding taxations. Its absence of online computerized tax collection procedures that share all government institutions, including regional administration. Though Somalia's capital city has considerably improved over the past years, most federal government institutions have still opted to manage taxation within the local government structures. To establish a tax administrative system, the government should determine and undertake with the critical sectors in the economy, including the telecommunication companies, banks and remittance, and hotel and significant restaurant sectors (World Bank Group, 2017).

Table 2: Revenue Policy Reform (RPR)

\begin{tabular}{|l|l|l|}
\hline & $\mathbf{2 0 1 8}$ & $\mathbf{2 0 1 9}$ \\
\hline Tax policy, increase in exercise tax rate on: & $\mathbf{1 8 . 0}$ & $\mathbf{1 8 . 0}$ \\
\hline Kat from \$ to 2.5 per kg & 13.0 & 12.0 \\
\hline Airlines sales tax and fees & 3.3 & 3.3 \\
\hline Higher and increased progressively rate of rental income tax (from 5\% to 15022\%) & $\mathbf{0 . 5}$ & $\mathbf{0 . 5}$ \\
\hline Corporate income tax & 1.2 & 2.2 \\
\hline Tax administration Measures & $\mathbf{2 5 . 6}$ & $\mathbf{2 . 6}$ \\
Personal Income (hotels. Electricity, telecoms, foreign workers and NGOs) 3/ & 5.5 & 6.4 \\
In-housing revenue collection 4/ & 1.4 & - \\
Sales telecommunication companies & 6.5 & 6.5 \\
Sales tax on hotels & 0.2 & 0.2 \\
Collect Sales tax on imported goods by values at the airport & 12.0 & 13.0 \\
Sales tax on consumer electricity companies & - & 0.5 \\
\hline New Revenue Measures: & $\mathbf{2 3 . 8}$ & \\
Annual tuna license & 3.0 & 12.0 \\
Airport fess collected by ICAO/5 & 2.0 & \\
Telecommunication licensing and spectrum fees & 4.8 & 2.0 \\
Visa charges & \\
Airport fees-Favori & \\
\hline
\end{tabular}

IMF, (2019) "Somalia First Review Under the Staff-Monitored Program-Press Release; And Staff Report”" published by IMF, Washington, DC.

The above table shows Somalia's government anticipated to increase and modernized its revenue collection. According to the IMF report indicates that the new revenue measures have a direct impact on the national budget and boost economic growth. In contrast, the government should have the capacity to deliver public services and pay government expenditure regularly (IMF, 2019:8).

\subsection{Civil service and administrative policy reform}

Public sector employees deemed as public servants; have an agreement, legitimate and managerial conditions following which government employees are hired. Of importance, the efforts to reach a general description of the civil service are sophisticated by the infinite types that it may take and the various extent of civil servants that can be incorporated (Avis, 2015).

Somalia's public sector has been facing challenges with producing competent public servants. However, in the beginning, the civil service reform program led by Prime Minister Abdirasak took place in 1964-67. During the reforms, thousands of directors and junior civil servants were dismissed from the public service. Despite that, 
and the 1967 military coup disrupted Prime Minister Abdirasak reform agenda efforts. The collapsed state in 1991 led entirely devastated an already useless public bureaucracy. In 2006, The transitional federal government led by former president Mr. Yusuf built and introduced the first civil service law entitled law 11 and approved by the interim federal parliament. The bill turned the foundation for Somalia's aftermath conflict public service. It followed by the appointment of the commission of the National Civil Service Commission (Wasuge, 2018). According to article 7 of law No.11, it instructs the national civil service commission to recruit entire public services as an independent body. It indicated that the current public employee estimated over 5000 civil services opted by the ministries, MPs, and other public officials who influenced the government. Those federal employees are primarily hired based on nepotism, clanship, and friendship. By contrast, Under the procedure referred to article 118 of the constitution, the civil servants and public employees, long-term jobs with the government can be deserved solely through an open competition, unless in given conditions outlined by law (Constitution, 2012).

Subsequent governments failed to develop a definite employment retention process and build condition for merit-based public service recruitment and open competition. Few public employees have limited access to get the required capacity building and professional development for their work and terms. Still, the state did not belong to civil service institutes that trained public services. Moreover, the salaries of federal employees have not received based on a job promotion, and even in previous years, the civil servants did not receive their pay regularly. These essential obstacles resulted in a bureaucratic framework(cadre) who could not provide critical government services (Wasuge, 2018). The current pay system starts from grade A university graduate, B completed secondary school, $\mathrm{C}$ technicians, all positions ranked senior Admi and Administrators, professional and Support Staff. There is no seniority if she/he works the government institution for 10 years and fresh employees both will earn the same salary according to their certificates.

\section{Conclusion}

The evidence from this study suggests that relevant stakeholders should involve in all the phases of the publicsector reform, which is believed to bring a greater sense of ownership. It should be noted that the aim of undertaking public sector reform is to attain good governance. In comparison, it must be strengthening the capacity of those institutions responsible for promoting good governance. The public employees must participate in financial management reforms, particularly the ministry of finance, also government agencies, and members of civil society. The Staff of who works with financial institutions should provide technical training to implement financial procedures and promote transparency. That will encourage investors and donors to identify their priorities needs and lead the nation to achieve sustainable development and economic growth while also have positive effects on good governance.

Moreover, the study notes that recent tax reform was made by the government to increase domestic revenue. In that regard, it is essential to reconsider developing federal tax administrative policies that help the government unify its tax collection mechanism. I would suggest that having strong leadership and a better strategy for economic analysis is indispensable. To control anti-corruption will determines social service delivery and further or support effectiveness and approachable to the citizens, whereas persistent inside the limit of political feasibility. To fight corruption, the government should initiate effective laws that promise as a tool for promoting transparency. As we know, Somalia ranked the most corrupted country globally; therefore, the anti-corruption campaign will have positive effects on good governance.

\subsection{Policy Recommendations}

\subsubsection{Extensive reform scheme required}

Somalia needs a robust and extensive reform process if tangible changes are to be experienced. There have been some efforts to promote reforms in the past years, but these have largely been supported by the World Bank, EU, and the united nations development program (UNDP). These institutions despite their conviction cannot be solely relied upon to bring all the changes in Somalia. The government and the people must lead the way to be showing patriotism and dedication to move the country forward. To begin with, an intelligently, unbiased, and uniting constitution needs to be urgently written and subjected to public opinion before being implemented. The central aim of this constitutional reform process is to provide the reform agenda a sound basis to operate from. The new constitution should demarcate the distribution of power between the three arms of government at the central level and define the powers and relationship between the central government and the local governments. Once each arm and level of government has been allocated its functions and responsibilities, the constitution should then create several independent offices such as superior Auditor General, the Ombudsman office, Office of Administrative Justice, the Public Service Commission, Office of the Public Prosecutor, National Ethics and Anti -Corruption Commission and others. These new or restructured institutions should be granted sufficient powers and independence to ensure they protect and defend the public interest. 


\subsubsection{Restructuring the public Sector}

Although the previous reforms had aimed at reforming the public sector, several important measures have not been adopted. Thus, to ensure a merit-based recruitment process, all positions should be publicly advertised through the public service commission website and the names of the shortlisted candidate, their academic and work experience also made public. Once the candidates are appointed, complaints about the process can be handled through the office of administrative justice. Secondly, a Somali School of Government (SSG) needs to be established with the goal of training civil servants on skills, ethics, and national philosophy. Apart from that, the government needs to integrate technology in governance (e-Government). There needs to be an integrated public finance management system to handle the public finance and procurement system in a traceable and secure manner. The government needs to also adopt an e-citizen service where different services can be accessed online without following too many bureaucratic processes.

\subsubsection{Adopting efficiency, transparency, and public participation}

An open survey report published by international budget partnership shows Somalia's public participation found that there is little chance for the public to involve in the federal budget process. Moreover, budget oversight, the role of parliament, and the audit department in Somalia also given scant. Noteworthy, public participation in budgeting is essential to achieve positive results connected with higher budget transparency. Simultaneously, similar possibilities should be provided over the budget process by the executive, the parliament, and the audit department (IBP, 2017). Decision making in Somalia is highly centralized, making service delivery and decision making a long and tedious process even though it adopted federalism. Still, the implementation hindered by internal conflict and instability.

To address this problem, best practices in decision-making that may require more decentralizing some decision-making authorities to lower administrative units will be required. Secondly, when government programs are highly centralized, there is opaqueness and the public as well as investors and donors cannot know what the government is planning. Therefore, measures that will ensure transparency in the public sector especially when it comes to resource allocation and utilization, public service recruitment, budgeting, and promotion. equally important is the question of public participation which has become central in promoting good governance practices. The voice of citizens needs to be represented in policy and decision-making processes such as budgeting, project implementation, constitutional changes as well as key reforms. This way not only will the citizens be highly involved in the management of their country, but also, they will be able to.

\section{References}

Avis, W. (2015). Factors impotant to etbalishement, renewal or rehabilitation of the civil services(rapid literature review). Brirmingham, UK: University of Brirmingham.

Ayee, J. (2008). Reforming the african public sector:Retrospect and prospects. Dakar: CODESRIA.

Ayee, J. R. (2015). Public Sector Reform in Africa: State-of-the-Art . Commonwealth Association for Public Administration and Management, 2.

Balogun, J.-M. K. (2005). Regional Forum on Reinventing Govornment in Africa: Repoitioning the Public Sector for the Challenges of Nepad. Sandton Convention Center, 3 .

Bank, T. W. (2008). Public Sector Reform:What Works and Why : IEG Evaluation of World Bank Support. Washintong D.C: The international Bank for Reconstruction and Development .

Bank, T. W. (2017). Proress Report: Mult Partner Fund. Somalia: The World Bank: Publication Disclosure Authorized.

Dalsan, R. 2018. Somalia: Mogadishu port Tax cheif and six staff arrested over corruption . Retrieved from Retrived www.radiodalsan.com, Accessed on 2020.

Grindle, S. M. (2013). Public Sector Reform as Problem-Solving Comment on World Bank's Public Sector Managment Approach for 2011 to 2020. Intenational Review of Adminstartive Sciences , 298.

Group, T. W. (2008). Public Sector Reform: What Works and Why. Washington DC 20433: The International Bank for Reconstruction and Development The World bank.

Group, W. b. (217). Somalia economic update: to mobilizing demostic revenue to rebuild somalia . Nairobi: The World bank group.

Gumede, K. B. (2014). Governance,Restructuring and the New Public Managment Reform: South African Perspectives . Educational and Socail Research MCSER, 43.

Helao, T. (2015). An Evaluation of Good Governance and Service Delivery at Sub-National Levels in Namibia. Thesis:University of South Africa, viii.

Holmberg \& Rothstein. (2011). Dying of corruption . health economics, policy and law, Vol. 6, Issue 04(september), pp.529-547.

Hood, C. (1991). A Public Managment for all Seasos . Public Adminstartion. 68(1): 3-9.

IBP. (2017). Somalia Open budget survey. Retrieved from Retreived : www.internationalbudget.org, accessed on 17.8.2020 
IMF. (2019). Somalia: First review under the staff-monitored program-Press release; and staff report. Washington, D.C: IMF.

IMF., 2020. Somalia poverty reduction strategy paper-joint staff advisory note. Retreived:www.imf.org: Accessed on Auguest 5, 2020

Integrity, G. (2016). Business-Anti-Corruption. Report publisherd BAC, 2108.

Jibril, H.(2017). Structural Adjustment Programs: Dependency and Poverty in Somalia and Rwanda, . Retrieved from Retrieved: www.thestandrewseconomist.com, From, Auguest 3, 2020.

Johnston, M, 2002. Good governance: Rule of law, transparency, and accountability. Colgate University: Retreived: www.researchgate.net, Accessed on August 92020.

K. et.all, (2016). Public Sector Reform in Africa : Acollection of Essays. Canadian Social Science Vol.12, No.10, PP. 1-20 26.

MoF, (n.d.). Appropriation act for 2019 budget. Retrieved from Retrieved : www.mof.gov.so report, S. C, Business-Anti-Corruption, Accessed on August 6, 2020.

Reuters. 2018. Somalia, Retrieved www.af.reuters.com. Accessed on july 2020.

Ronan, K. (2017). Somalia: overview of corruption and anticorruption . Norway: CMI.

Simone Bunse and Verena Fritz. (2012). Making Public Sector Reforms Work Political and Economic Context, Inventives, and Strategies. Policy Research Working Paper 6174 World Bank, 1.

Schacter, M. (2000). Public sector reform in developing countries: issues, lessons and future directions. Ottawa: : Candadian international development agency .

Swaroop, V. \& Rajkumar, S.A.,. (2002). Public spending and outcomes: Does governance matter? Washington, Dc.: Policy researhc working paper, issue 2840(May)

Tran. (2019, Accessed on Auguest 5, 2020). Review of public adminstartion reform in somalia: A pre-condition for functioning state. Retrieved from Tran Consulating LTD: Retreived: www.consultingtran.com

Waber, T. (2017). Implementation of Public Sector Reforms. Thesis: University of Twente, 1.

Wasuge, M. (2018, April 14). Reforming civil service in somalia. Retrieved from Accessed on August 8, 2020 : Retreived: www.somalipublicagenda.org

Westhuizen, J. V. (2005). Public Sector Reform: A Comparative Perspective on Selected Countries in Subsaharan Africa. 142-143.

World Bank, G. (2018). Poverty and shared prosperity. Washington: DC: Intrenational Bank for reconstruction and development.

WorldBank. (2015). Somalia economic update, edition no: 1 Roprt on transition amid risks with a special focus on intergovernmetal fiscal relations. Nairobi: The world Bank.

The World Bank 2020. Overview in Somalia. Retrieved www.worldbank.org form September 9, 2020. 